\title{
Barriers Affecting the Passion and Entrepreneurial Intention of University of the ITSON
}

\author{
Luis Enrique Valdez-Juárez ${ }^{1}$, Domingo García-Pérez de Lema ${ }^{2}$ \& Elva Alicia Ramos-Escobar ${ }^{1}$ \\ ${ }^{1}$ School of Management, Technological Institute of Sonora, Mexico \\ ${ }^{2}$ School of Management and Economics, Polytechnic University of Cartagena, Murcia, Spain \\ Correspondence: Luis Enrique Valdez-Juárez, School of Management, Technological Institute of Sonora, \\ Guaymas Sonora, Mexico. E-mail: levaldez@itson.edu.mx
}

\author{
Received: December 10, $2019 \quad$ Accepted: January 30, $2020 \quad$ Online Published: April 18, 2020 \\ doi:10.5539/ies.v13n5p94 \\ URL: https://doi.org/10.5539/ies.v13n5p94
}

\begin{abstract}
The purpose of this article is to analyze the internal and external barriers experienced by university students of the Technological Institute of Sonora (ITSON) for the development of entrepreneurship. The study is focused on a sample of 733 students from the areas of engineering, administrative sciences, and social sciences. The field work was carried out during the months of May to September 2018. The controlled statistical technique for data analysis was the structural equation model (SEM) with the support of SMARTPLS software version 3.2.8. The results have revealed that internal creativity barriers are the ones that most negatively impact the entrepreneurial passion of ITSON university students. This research contributes to the development of entrepreneurship literature from the area of psychology and business sciences through planned behavior theory, cognitive theory, and self-determination.
\end{abstract}

Keywords: creativity, entrepreneurial intention, entrepreneurial passion, university students

\section{Introduction}

In these times of social, economic, and environmental problems, most regions of different latitudes are focusing on resolving them through government policies with a traditional approach, but some nations are also launching new reforms aimed at improving education (Drucker, 2012; Zahra \& Wright, 2011). Therefore, constant learning and training are and will be the key to preparing the young population in jobs and in ventures that have not yet been discovered (Real, Roldán, \& Leal, 2014; Zahra, Sapienza, \& Davidsson, 2006). With the enormous speed of globalization in open markets, in innovation and in new information and communication technologies, regions of all latitudes will have to strengthen their economic, educational, political, and social policies to improve the quality of life of the inhabitants and be in the elite of competitive markets (European Comission, 2018; Jiménez-jiménez \& Sanz-valle, 2011). In developed countries, the level of training has been on the rise in the last two decades and one of the strategies to solve socio-economic problems has been the promotion of entrepreneurial education (Ernest, Matthew, \& Samuel, 2015; GEM, 2018). In counterpart in less developed regions, some data issued by the OECD (2017) report that the population of young people in Latin America and the Caribbean (LAC) between ages 15 and 29 years amounts to more than 163 million, which is equivalent to $25 \%$ of the total population of this region in the United States. Despite notable progress in education during the last decade, less than a third of young Latin Americans between ages 25 and 29 years have received some entrepreneurial and innovative education in the universities. Young entrepreneurs in Latin America tend to have less education, on average, than their counterparts in first-world economies (CEPAL, 2018; UNESCO, 2018). Various entrepreneurs have expressed that this is due to a human capacity, which is strongly related to the level of creativity, the capacity for innovation, passion, and the intention to generate new innovative ideas (Drucker, 2012; Zahra, 2008). Creativity is a human process that consists acquisition of knowledge, imagination, and the implementation of the ideas generated for later evaluation (value propositions) (Drucker, 2014; Yar, Wennberg, \& Berglund, 2008) and actions that later become innovative facts (Mishra \& Zachary, 2014; Śledzik, 2013). However, for the development of creativity and entrepreneurship, there are some obstacles (intrinsic and extrinsic): (1) from the internal point of view: (a) the lack of motivation or disinterest to undertake, (b) fear of failure, (c) lack of entrepreneurship training, and (d) cultural and social paradigms (GEM, 2018; Mahendra, Djatmika, \& Hermawan, 2017; Nawaser, Khaksar, \& Shakhsian, 2011); (2) from an external point of view: (a) 
the lack of economic and financial resources, (b) little government support, (c) lack of infrastructure, (d) lack of entrepreneurial training at an early age, (e) internal and external market regulations, and (f) little investment in research, development, and innovation (R\&D\&I) (GEM, 2018; Zahra \& Wright, 2011). In the theoretical and empirical review from the point of view of psychology and business sciences, it has been detected that there are few studies in Latin America focused on the influence of barriers to the development of creativity and its effect on intention and in the entrepreneurial passion in the student context at university level (GEM, 2018; Stewart \& Roth, 2007; Zahra, 2008). In most of the studies analyzed, they focus on studying these phenomena in economies of scale and in developed countries. Therefore, this article focuses on analyzing these variables related to the barriers to university entrepreneurship students of the Technological Institute of Sonora (ITSON-Instituto Tecnológico de Sonora). The objectives of the research work are the following: (1) to analyze the effect of barriers to creativity in entrepreneurial intention and on entrepreneurial passion, and (2) to examine the effect that entrepreneurial passion has on the entrepreneurial intention of ITSON university students.

\section{Review of the Hypothesis Literature and Development}

\subsection{The Barriers of Creativity in Entrepreneurial Intention in the University Context}

Entrepreneurship has been one of the topics most addressed in the last three decades by researchers in the social sciences (psychology) and business sciences. There are different contexts of entrepreneurship that have been approached from the theory of planned behavior, among the most cited are the social, business, and university (Ajzen, 1991). Starting from the social and business context, entrepreneurship has been visualized as the ability of the individual to create, face risks, and detect latent opportunities in a society. This model is based on the intention of the individual and contemplates three factors: (1) the attitude toward entrepreneurship, (2) subjective norms, and (3) the perceived control over the creation behavior of the organization. In addition, entrepreneurship can be developed from within an organization or as a new idea generated from the creativity of the individual's thinking. From a psychological perspective, entrepreneurial intent has been one of the topics with the greatest interest by scholars in the area, such is the case of McClelland (1965), Littunen (2000), and Kirby (2004); These researchers argue that individuals have achievement needs, power needs, and affiliation needs, this allows people to have internal impulses that moves them to develop their creativity and generate new ideas. Another of the theoretical currents from a psychological perspective that reinforce the entrepreneurial intention is the theory of self-determination (SDT). In their conceptual postulates on motivation, experts have concluded that a psychological theory is motivational only if it explores energy (generated in needs) and if it is directed toward internal and external impulses, orienting action toward satisfying needs (Ryan \& Deci, 1985, 2000). In this same direction, SDT assumes that human beings are very active organisms with tendencies toward growth to dominate the environments and to integrate the new experiences that are in the internal and external environment (Ryan \& Deci, 2017). These actions lead them to face opportunities, risks, and barriers to achieve efficiency and meet the full variety of their needs, such as entrepreneurial intent and entrepreneurship (Deci \& Ryan, 2016). Authors, such as Schumpeter (2000) and Drucker (2014), have stated that entrepreneurship is creative and innovative destruction, that is, it is a strategic action that breaks down and breaks with existing paradigms (common goods and services) of consumers in a potential market. From the university point of view, entrepreneurship has been visualized as a complementary assignment to the student's training, but at present, educational institutions are incorporating greater training and education programs oriented toward entrepreneurship (Sirelkhatim \& Gangi, 2015). However, university students face different limitations and/or barriers that prevent them from developing their creativity for business creation. Among the most prominent are the internal ones: these barriers are associated with socio-logical aspects (gender, age, distrust-locus control) (Din, Anuar, \& Usman, 2016; Mueller \& Thomas, 2001), demographic (family influence, poor training in entrepreneurship) (Zellweger, Sieger, \& Halter, 2011), and socioeconomic (little access to financing) (Smith \& Beasley, 2011), and external ones are associated with socio-cultural aspects, such as fear of failure and fear of economic environment situations (recession and financial crises) (Robertson, Collins, Medeira, \& Slater, 2003; Rosique-Blasco, Madrid-Guijarro, \& García-Pérez-de-Lema, 2018). There are some studies that relate the barriers of creativity with entrepreneurial intention, which point out that when there are greater barriers (fear of failure, locus control, and poor academic preparation in entrepreneurship), the entrepreneurial intention is negatively affected, this is mainly due to external factors, such as poor access to financing and macro-economic phenomena (Fatoki \& Patswawairi, 2012; Rosique-Blasco et al., 2018). In this same direction, external barriers to the development of creativity, such as cultural prejudices and social paradigms, are factors that inhibit entrepreneurial intent (Ip, Liang, Wu, Law, \& Liu, 2018; Yar et al., 2008). Other research affirms that creativity is an individual capacity that generates greater motivation and intention to undertake in university students (Smith, Sardeshmukh, \& Combs, 2016; Zampetakis \& Moustakis, 2006). On the other hand, authors, such as Bagheri (2011) and Bagheri, Lope Pihie, \& Krauss 
(2013), have concluded that students at an early age before starting their university studies have high entrepreneurial intent and see less obstacles to developing creative ability. Some schools have managed to implement and strengthen some teaching practices through the case study and business simulators, actions that eliminate obstacles to entrepreneurial intent. However, other authors point out that the main barriers to the development of creativity and that drives entrepreneurial intent are emotions and attitudes (Gomes da Costa Pedro Mares, 2016; Kalitanyi \& Bbenkele, 2019). From the previous context, the following hypotheses are proposed (view Figure 1):

H1. The greater intrinsic barriers to creativity, the lower entrepreneurial intentions in university students.

H2. The greater extrinsic barriers to creativity, the lower entrepreneurial intentions in university students.

\subsection{The Barriers of Creativity in the Entrepreneurial Passion in the University Context}

Entrepreneurial intention and entrepreneurial passion are capacities that individuals show when generating new ideas; however, there are barriers that impede the development of creative thinking, and they impact in two directions to the passion to start a new business (positive and/or negative) (Smith \& Beasley, 2011). Cognitive theory and self-determination have suggested that individuals create and move through impulses that move them toward clearly preestablished goals, achievement, and self-realization (Shepherd, Patzelt, Shepherd, \& Patzelt, 2018). Therefore, from the point of view of psychology, the individual's knowledge has become a resource and a capacity that allows for effective decision making and more rational human behavior (De Carolis \& Saparito, 2006; Mitchell et al., 2007). This theory (entrepreneurial behavior) contemplates a series of elements and capacities that an individual possesses for the development of the intention and passion toward entrepreneurship, among which is the capacity for reasoning, the ability to communicate, the creative capacity, and the capacity for innovation (De Carolis \& Saparito, 2006). That is why entrepreneurs have the ability not only to detect opportunities but also perceive and measure risks based on their cognitive ability. Entrepreneurial passion can be defined as positive emotions and feelings that constantly perspire and motivate a future entrepreneur (GEM, 2017; Gibb, 2007). Entrepreneurial passion is a combination of abilities and emotions, such as joy, the enthusiasm that a person has to face business challenges and challenges (Biraglia \& Kadile, 2017; Cardon, Wincent, Singh, \& Drnovsek, 2009a). Recent studies have shown that barriers to creativity (intrinsic and extrinsic), such as fear of failure, introversion, self-mistrust, low self-esteem, and social stereotypes, seriously affect the full development of entrepreneurial passion (create, invent, and develop) (Bhansing, Hitters, \& Wijngaarden, 2018; Biraglia \& Kadile, 2017). These factors have been limiting the creation of new ventures in the university context, which has led universities to adopt new business strategies that allow them to have graduate students with a greater culture and entrepreneurial passion (Liu \& Gu, 2017; Rosique-Blasco et al., 2018). From the previous context, the following hypotheses are proposed (view Figure 1):

H1a. The greater intrinsic barriers to creativity, the lower the entrepreneurial passion (create) in university students.

H1b. The greater intrinsic barriers to creativity, the lower the entrepreneurial passion (develop) in university students.

H1c. The greater intrinsic barriers to creativity, the lower the entrepreneurial passion (in-sale) in university students.

H2a. The greater extrinsic barriers to creativity, the lower the entrepreneurial passion (create) in university students.

H2b. The greater extrinsic barriers to creativity, the lower the entrepreneurial passion (develop) in university students.

H2c. The greater extrinsic barriers to creativity, the lower the entrepreneurial passion (inventing) in university students.

\subsection{The Entrepreneurial Passion and the Relationship with the University Entrepreneurial Intention}

Literature has stated that entrepreneurial passion is the central axis and the vital organ that moves people toward entrepreneurship. Experts on the subject, such as Cardon et al. (2009), have stated that entrepreneurial passion is the "accessible intense positive feelings that the individual consciously experiences through participation in business activities associated with roles that are significant and relevant to the identity of an entrepreneur." From the theoretical perspective of the motivation that drives the entrepreneur toward its realization, it has been shown that the mixture between the feelings and the cognitive aspects of the entrepreneurial individuals are the key factors that strengthen the entrepreneurial spirit and action. For example, some authors, such as Kauanui, Thomas, 
Rubens, and Sherman (2010) and Cardon, Gregoire, Stevens, and Patel (2013), express that entrepreneurial passion integrates two dimensions: intense positive feelings and centrality of identity. These factors are related to other aspects, such as emotion and cognition, elements that play a decisive role in entrepreneurship. One of the most cited conceptual models in studies on entrepreneurial passion is that developed by Cardon, Wincent, Singh, and Drnovsek (2009b), which contemplates the following dimensions: (1) goals related to cognition (challenges, commitment and effort), (2) entrepreneurial behavior (creative, persistent, and absorption), and )3) business effectiveness (opportunity recognition-inventor identify, innovativeness, venture creation, and venture growth). Therefore, this study contemplates the analysis of the variable of entrepreneurial behavior. Entrepreneurship education has been one of the most recently studied topics and more in the university context, not only by researchers but also by global organizations which are focused on predicting the abilities of individuals to face the challenges of the present and future (GEM, 2018; OECD, 2019). From the university, students are encouraged toward entrepreneurship with the analysis of case studies and readings on success stories in the business context (OECD, 2019; UNESCO, 2018). Recently, some institutions have been incorporating entrepreneurial training programs and business incubation and acceleration projects (Hornsby, Messersmith, Rutherford, \& Simmons, 2018). From thinking and/or cognitive current, individuals who are potential entrepreneurs usually detect opportunities and minimize latent risks, this is generally achieved through converting experiences into applied knowledge (Miller \& Le Breton-Miller, 2017; Tipu, 2015). Studies in this context have shown that the behavior and entrepreneurial passion of individuals is focused on creating, developing, and inventing new ways of doing things, facing problems, and/or creating new prototypes and that it also manages to develop positive impulses, which promote the strengthening of the intentions to undertake (Costa, Santos, Wach, \& Caetano, 2018; Neneh, 2019). From the theoretical and empirical review, we emit the following hypothesis (view Figure 1):

H3a. The greater entrepreneurial passion (creating), the greater entrepreneurial intention of the university student. H3b. The greater entrepreneurial passion (to develop), the greater entrepreneurial intention of the university student.

H3c. The greater entrepreneurial passion (inventing), the greater entrepreneurial intention of the university student.

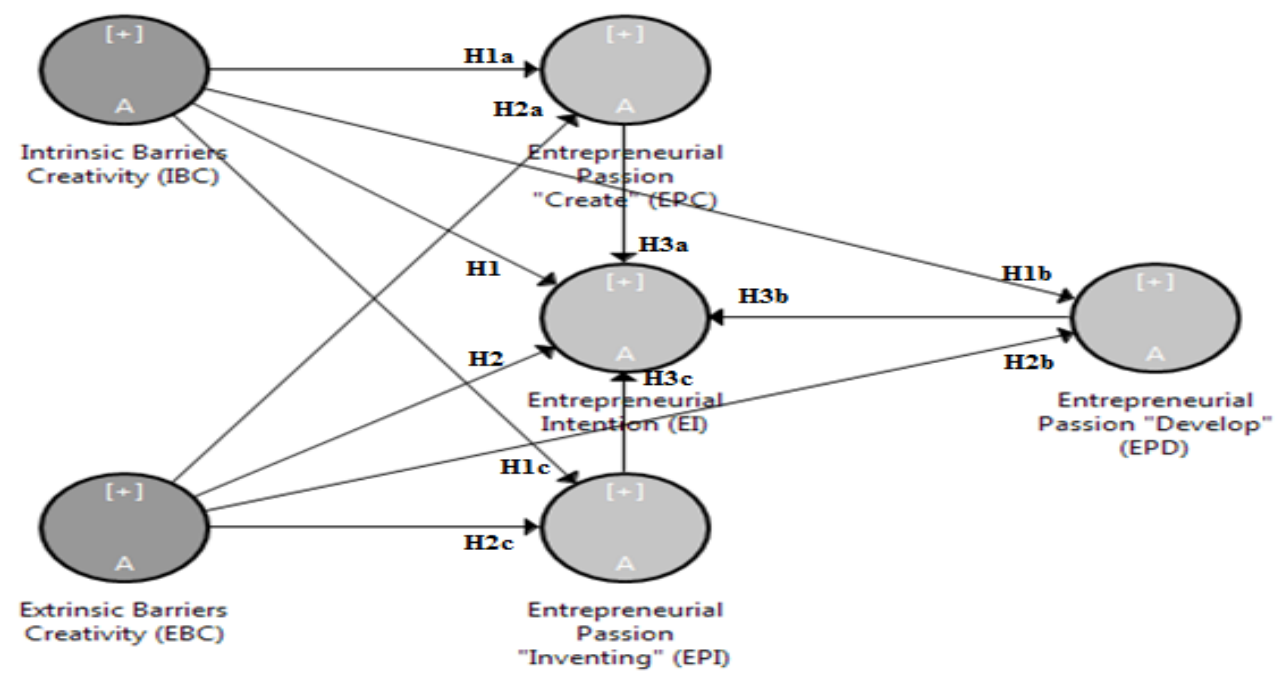

Figure 1. Theoretical model

Figure 1 shows the proposed theoretical model of the investigation. In this same Figure 1 you can see the constructed structural relationships (independent variables with dependent variables) to verify the results of the hypotheses.

\section{Methodology}

The study is quantitative and based on the principles of stratified sampling for finite populations. The population is made up of students enrolled in ITSON in its three academic units established in the cities of Guaymas, Obregon, and Navojoa Sonora in Mexico. The number of students in the areas of engineering, administrative 
sciences, and social sciences is the focus of this study, and the information has been obtained from existing data in the school's registration department of the institution. The sample size was determined to ensure that the maximum margin of error for the estimation of a proportion (relative frequency of response in a specific item of a question) was less than 0.03 points with a $95 \%$ confidence level (see Table 1). The technique for collecting the information was through an online questionnaire addressed to the student through google docs (see Appendix A). The field work was carried out during the months of May to September 2018. Finally, a sample of 733 surveys was obtained, a figure that represents a response rate of $74.34 \%$ (see Table 2).

Table 1. Sample determination

\begin{tabular}{ccc}
\hline & Data & Conversion \\
\hline $\mathrm{N}$ & 13,000 & Population \\
$\mathrm{p}$ & $50 \%$ & 0.50 \\
$\mathrm{q}$ & $50 \%$ & 0.50 \\
$\delta$ & $95 \%$ & 1.96 \\
$\mathrm{e}$ & $3 \%$ & 0.03 \\
$\mathrm{n}$ & 986 & Sample \\
\hline
\end{tabular}

Note. Table 1 shows the description of the formula for populations under 500 thousand subjects. $\mathrm{N}=$ Population, $\mathrm{p}=$ Probability in favor, $\mathrm{q}=$ Probability against, $\delta=$ Degree of reliability, $\mathrm{e}=$ Margin of error, $\mathrm{n}=$ total of the sample.

Table 2. Sample characteristics

\begin{tabular}{lcccc}
\hline Bachelor's degree & Average age & Women & Men & Total \\
\hline Engineering (Industrial and Software) & 23 & 94 & 182 & 276 \\
Administrative Sciences (Administration, Tourism and Accounting) & 22 & 132 & 118 & 250 \\
Social Sciences (Education and Psychology) & 22 & 116 & 91 & 207 \\
Total & 22.33 & 342 & 391 & 733 \\
\hline
\end{tabular}

Note. Table 2 shows the total of the students participating in the research and their main characteristics such as age and gender.

\subsection{Measurement of the Variables.}

For barriers to creativity, this construct was divided into 1) intrinsic barriers to creativity and 2) extrinsic barriers to creativity. For statistical analysis and validation, it was measured as a first-order, one-dimensional, reflective type construct in A mode. The studies of Ajzen (1991), Ajzen (2011) and Audretsch and Belitski (2013) have been taken as a reference to develop the measurement scales of this construct. To measure the intrinsic barriers, 4 questions were structured in the questionnaire and provided to the student. Extrinsic barriers were measured through 3 structured questions in the questionnaire that were also provided to university students for their response to identify the main barriers (internal and external) that affect the development of creativity and the entrepreneurship. The options for answering the questionnaire are based on a 7-point Likert scale with 1 as strongly disagree and 7 as strongly agree. All the questions comply with the internal consistency and validity indicators, the factor loads are in a range of 0.661 to 0.797 , and all significant at $99 \%$, in addition to exceeding the allowed indicators in the composite reliability (0.846 and 0.777) and alpha of Cronbach (0.686 and 0.763).

Entrepreneurial Intention (EI). This construct was measured in a one-dimensional reflective type in A mode. Based on the review carried out on the theories that relate to creativity with entrepreneurial intention, this variable was measured taking reference to the studies developed by Smith and Beasley (2011), Ajzen (2011), and Drucker (2014). The variable has been measured with 5 questions formulated in a questionnaire addressed to university students expressing their answers related to the intention they have to start a business. For this, a 7-point Likert scale has been used with 1 as total disagreement and 7 as total disagreement. All questions comply with the internal consistency and validity indicators, the factor loads are in the range of 0.812 to 0.922 , and all values are significant at $99 \%$, in addition to exceeding the permitted thresholds of composite reliability (0.940) and Cronbach's alpha (0.929).

Entrepreneurial Passion (EP). This construct was measured in a one-dimensional reflective type in A mode. To develop the measurement scales for this construct, studies developed by Zahra and Nambisan (2012), Cardon et al. 
(2013) and by Drucker (2014). This variable was measured using a 7-point Likert scale, with 1 as total disagreement and 7 as strongly agree. This variable has been broken down into the following: (1) passion to create, measured with 3 questions; (2) passion to develop, measured with 4 questions; and (3) passion to invent, variable measured through 4 questions. The questions were structured in a questionnaire aimed at university students. All the questions comply with the internal consistency and validity indicators, the weights are in the range of 0.860 to 0.922 , and all are significant at $99 \%$, in addition to exceeding the permitted thresholds of composite reliability $(0.934,0.939$, and 0.930$)$ and Cronbach's alpha $(0.894,0.913$, and 0.900$)$.

\section{Results}

\subsection{Measurement Model}

This section shows the convergent and discriminant validity of the proposed theoretical model. First, the average extracted variance (AVE) is analyzed; this indicates the average amount of the variance explained by the indicators of the construct. Our AVE values range from 0.544 to 0.826 , these results should be above 0.500 , as indicated by Hair Jr et al. (2010). Also, the discriminant validity of the constructions in the model was verified through the analysis of the square root of the AVE. The results (diagonal) of the vertical and horizontal AVE are below the correlation between the constructs (Henseler, Ringle, \& Sarstedt, 2015). Additionally, to verify the discriminant validity, the Heterotrait-Monotrait Ratio (HTMT) test was performed, indicating that the correlation values must be below 1 (Henseler, Ringle, \& Sarstedt, 2015). This checks and detects that there is no anomaly (see Tables 3 and 4). Our results provide adequate convergent, discriminant validity, and adequate model reliability.

Table 3. Convergent and discriminant validity

\begin{tabular}{cccccccc}
\hline & AVE & BExt & BInt & IEMP & PE (Creative) & PE (Develop) & PE (Inventiveness) \\
\hline BExt & 0.544 & 0.738 & & & & & \\
BInt & 0.580 & 0.524 & 0.761 & & & & \\
IEMP & 0.758 & 0.065 & 0.132 & 0.871 & & & \\
PE (Creative) & 0.826 & 0.046 & 0.146 & 0.599 & 0.909 & & \\
PE (Develop) & 0.793 & 0.076 & 0.155 & 0.509 & 0.815 & 0.891 & \\
PE (Inventiveness) & 0.769 & 0.059 & 0.169 & 0.468 & 0.756 & 0.767 & 0.877 \\
\hline
\end{tabular}

Note. Table 3 shows the results of the discriminant validity and the value of the average variance extracted less than 0.500 .

Table 4. HTMT discriminant validity

\begin{tabular}{ccccccc}
\hline & BExt & BInt & IEMP & PE (Creative) & PE (Develop) & PE (Inventiveness) \\
\hline BExt & & & & & & \\
BInt & 0.770 & & & & & \\
IEMP & 0.083 & 0.150 & & & & \\
PE (Creative) & 0.056 & 0.169 & 0.658 & & & \\
PE (Develop) & 0.089 & 0.175 & 0.552 & 0.901 & & \\
PE (Inventiveness) & 0.081 & 0.202 & 0.513 & 0.843 & 0.846 & \\
\hline
\end{tabular}

Note. Table 4 shows the results of the discriminant validity test through Heterotrait-Monotrait Ratio (HTMT), the values are below 1 .

\subsection{Structural Model}

The statistical technique of structural equations based on variance was used to verify the hypotheses raised in this investigation through the SmartPLS version 3.2.8 Professional program. The use of this statistical technique is appropriate in predictive, exploratory, and confirmatory research (Henseler, Hubona, \& Ray, 2016). Table 5 shows the results of the $\beta$ coefficient, the degree of significance ( $p$ value), the importance of the distribution of the values using Student's $t$ test and standard deviation. To test the hypothesis, the bootstrapping procedure was used with 5,000 sub-samples as recommended Chin (1998). 
Table 5. Hypothesis test results

\begin{tabular}{ccccccc}
\hline Hypothesis & Beta & T Score & $\begin{array}{c}\text { Standard } \\
\text { Deviation }\end{array}$ & P Value & $F^{2}$ & Results \\
\hline H1. BInt -> IEMP & -0.037 & 0.041 & 0.913 & 0.181 & 0.008 & Rejected \\
H2. BExt -> IEMP & -0.011 & 0.057 & 0.196 & 0.422 & 0.009 & Rejected \\
H1a. BInt -> PE (Creative) & -0.168 & 0.044 & 3.826 & 0.000 & 0.025 & Confirmed \\
H1b. BInt -> PE (Develop) & -0.159 & 0.043 & 3.716 & 0.000 & 0.020 & Confirmed \\
H1c. BInt -> PE (Invent) & -0.191 & 0.044 & 4.316 & 0.000 & 0.033 & Confirmed \\
H2a. BExt-> PE (Creative) & 0.042 & 0.046 & 0.915 & 0.180 & 0.011 & Rejected \\
H2b. BExt-> PE (Develop) & 0.008 & 0.049 & 0.153 & 0.439 & 0.006 & Rejected \\
H2c. BExt -> PE (Invent) & 0.041 & 0.048 & 0.855 & 0.196 & 0.005 & Rejected \\
H3a. PE (Creat) -> IEMP & 0.543 & 0.074 & 7.311 & 0.000 & 0.136 & Confirmed \\
H3b. PE (Develop) -> IEMP & 0.051 & 0.065 & 0.796 & 0.213 & 0.006 & Rejected \\
H3c. PE (Invent) -> IEMP & 0.011 & 0.057 & 0.192 & 0.424 & 0.004 & Rejected \\
\hline
\end{tabular}

Note. The table shows the results of the hypotheses (beta value), the value of $t$, the standard deviation, and the size of the effect of the predictive model through the $\mathrm{F}^{2}$ test, and the levels of significance according to the values of: *, $* *, * * *, 10 \%$ to $5 \%$, and $1 \%$, respectively.

Table 5 shows the results of the estimation of the structural equations made with PLS. We find empirical support for the hypotheses (H1a, H1b, H1c, and H3a), the other hypotheses have not shown a significant relationship. The hypothesis results show significant effects at $99 \%$. To evaluate the adjustment of the proposed model with the SEM techniques that are based on the variance through PLS, we consider: (1) the value of the trajectory coefficients; (2) the analysis of $\left(\mathrm{R}^{2}\right)$; and (3) the values of $\left(\mathrm{F}^{2}\right)$, which are significant individual measures to explain the predictability of the structural model (Chin \& Dibbern, 2010). Our strongest model coefficients are from $0.543 * * *$, $-0.191 * * *,-0.168^{* * *}$ and $-0.159^{* * *}$. For the analysis of the explained variance and the prediction quality of the model through $\left(\mathrm{R}^{2}\right)$, the results of $0.116,0.126,0.100$ of the variable Entrepreneurial Passion and for the Entrepreneurial Intention $(0.112, .042,0.056)$ show a low and medium effect (Hair, Jr., Sarstedt, \& Ringle, 2017). The value of $\mathrm{F}^{2}$ is measured according to the values of $0.02,0.15$, and 0.35 , and these indicate weak, medium, or large effect (Ringle, Wende, \& Becker, 2017). The analysis of $\mathrm{F}^{2}$ shows the results of the key relationships of the model with values of 0.005 and 0.136 . The statistical test $\mathrm{Q}^{2}$ (cross-validated redundancy index) is used to evaluate and test the predictive relevance of endogenous constructs in a model. The model was evaluated through the blindfolding technique (Ringle et al., 2017). Our values are above the value of (0), which demonstrates the existence of a remarkable explanatory quality of the model (Chin, 1998; Hair, Hult, Ringle, Sarstedt, \& Thiele, 2017). To explain more accurately the predictive effect, we have added a goodness of fit test. When the standardized value of the residual quadratic mean (SRMR) is in a range $(<0.08-0.1)$, there is an acceptable adjustment (Schuberth, Henseler, \& Dijkstra, 2018). Our result (0.090) confirms that the proposed model has an acceptable predictive quality and that the empirical results are consistent with the theory.

\section{Discussion and Conclusion}

In this section, the conclusions and discussions of the main findings of the study are issued, all based on theories of psychology, such as planned behavior, cognitive theory, and self-determination theory. The results show greater force in the proposed theoretical model, which negatively affects the development and strengthening of entrepreneurial passion, the internal barriers that university students emit (H1a, H1b y H1c). These findings confirm that university students have failed to overcome intrinsic barriers that are related to psychological factors, which consequently prevent them from focusing deeply on the ability to create, develop, and invent ideas that lead to entrepreneurship (H1a, H1b y H1c). These findings are aligned with the planned behavior theory and cognitive theory (Ajzen, 1991; Kautonen, van Gelderen, \& Fink, 2015; Begley, 1995) and with most empirical studies (Miller \& Le Breton-Miller, 2017; Robertson et al., 2003; Rosique-Blasco et al., 2018). In this same context, but with a positive direction, we find that entrepreneurial (creative) passion has an important effect on entrepreneurial intention (H3a), which allows inferring that ITSON university students put a greater emphasis on their creativity for the development of entrepreneurial ideas. These findings are aligned with the psychological theories of planned behavior and with various empirical studies (Kautonen et al., 2015; Kautonen, van Gelderen, \& Tornikoski, 2013; Mitchell et al., 2007; Rosique-Blasco et al., 2018). However, our study has not been able to empirically verify that external barriers have any significant effect mainly on entrepreneurial passion and, to some extent, on entrepreneurial intentions. This may be because university students are not paying attention to the external factors 
that impede the development of entrepreneurship and are focusing more on the locus of control, that is, on cultural, social and psychological aspects to launch innovative ideas and entrepreneurs (Bhola, Verheul, Thurik, \& Grilo, 2006; Smith \& Beasley, 2011). In the context of underdeveloped regions in the social, educational, and economic fields, some recommendations derived from the findings of the studies are issued, which can be strengthened in the establishment of policies focused on the development and training of entrepreneurship: (1) governments in conjunction with universities, research centers, and the business sector could articulate to work collaboratively and initiate training programs in entrepreneurial and business education (Carayannis, Barth, \& Campbell, 2012; Carayannis, Grigoroudis, Campbell, Meissner, \& Stamati, 2018); (2) universities should adopt new business models focused on creativity development and agile methodologies for entrepreneurial development (Teece, 2010; Zahra \& Wright, 2016; Zahra, Newey, \& Shaver, 2011); and (3) the different actors of the government, business, and education sector should promote new laws and educational reforms aimed at the development of entrepreneurship and sustainability (Carayannis et al., 2018; Jiménez, Palmero-Cámara, González-Santos, Gonzalez-Bernal, \& Jiménez-Eguizábal, 2015; UNESCO, 2018).

Under the theoretical cognitive and self-determination perspective, research has proven that the internal factors and impulses that human beings develop are the elements that determine the achievement of goals and the exploration of new environments. In this sense, we observe that one of the main contributions of research work focuses on the intrinsic barriers to the development of creativity and entrepreneurial intention. Therefore, individuals (students), who fail to reach professional self-realization (passion and entrepreneurial intention), are generally due to psychological inhibitors (lack of mental concentration, attention, retention, memory, perception, among other important ones) that are deeply rooted in the cognitive process (Ajzen, 2011; Miller \& Le Breton-Miller, 2017; Ryan \& Deci, 2000). These manifestations have also been experienced and argued by the theory of planned behavior and by the conceptual model of experience and entrepreneurial passion developed by Cardon et al. (2009b). Some limitations of the study are: (1) the surveys were conducted to university students of different semesters and from different areas from their subjective perception, in the future the sample can be segmented, evaluate their entrepreneurial behavior, and develop longitudinal studies; and 2) the statistical technique used in the study is based on the analysis of variance; in the future, other techniques that are related to the analysis of covariance may be used. Finally, given the importance of the barriers of creativity to the development of entrepreneurship in the university context and the global study of the value of entrepreneurship for social and economic stability, it is convenient to continue with the development of this type of research. To strengthen and complement research in this context, it is interesting to add new constructs and/or variables that contemplate entrepreneurial leadership and innovation.

\section{References}

Ajzen, I. (1991). The theory of planned behavior. Organizational Behavior and Human Decision Processes, 50(2), 179-211. https://doi.org/10.1016/0749-5978(91)90020-T

Ajzen, I. (2011). The theory of planned behaviour: Reactions and reflections. Psychology \& Health, 26(9), 1113-1127. https://doi.org/10.1080/08870446.2011.613995

Audretsch, D. B., \& Belitski, M. (2013). The missing pillar: The creativity theory of knowledge spillover entrepreneurship. Small Business Economics, 41(4), 819-836. https://doi.org/10.1007/s11187-013-9508-6

Bagheri, A. (2011). Malay Secondary School Students' Entrepreneurial Attitude Orientation and Entrepreneurial Self-efficacy: A Descriptive Study. Article in Journal of Applied Sciences, 11(2), 316-322. https://doi.org/10.3923/jas.2011.316.322

Bagheri, A., Lope Pihie, Z. A., \& Krauss, S. E. (2013). Entrepreneurial leadership competencies among Malaysian university student entrepreneurial leaders. Asia Pacific Journal of Education, 33(4), 493-508. https://doi.org/10.1080/02188791.2013.822789

Begley, P. T. (1995). Cognitive Perspectives on Values in Administration: A Quest for Coherence and Relevance. Educational Administration Quarterly-EDUC ADMIN QUART, 32, 403-426. https://doi.org/10.1177/0013161X96032003006

Bhansing, P. V., Hitters, E., \& Wijngaarden, Y. (2018). Passion Inspires: Motivations of Creative Entrepreneurs in Creative Business Centres in the Netherlands. The Journal of Entrepreneurship, 27(1), 1-24. https://doi.org/10.1177/0971355717738589

Bhola, R., Verheul, I., Thurik, R., \& Grilo, I. (2006, January 1). Explaining engagement levels of opportunity and necessity entrepreneurs. Retrieved from https://repub.eur.nl/pub/9705/

Biraglia, A., \& Kadile, V. (2017). The Role of Entrepreneurial Passion and Creativity in Developing 
Entrepreneurial Intentions: Insights from American Homebrewers. Journal of Small Business Management, 55(1), 170-188. https://doi.org/10.1111/jsbm.12242

Carayannis, E. G., Barth, T. D., \& Campbell, D. F. (2012). The Quintuple Helix innovation model: global warming as a challenge and driver for innovation. Journal of Innovation and Entrepreneurship, 1(1), 2. https://doi.org/10.1186/2192-5372-1-2

Carayannis, E. G., Grigoroudis, E., Campbell, D. F. J., Meissner, D., \& Stamati, D. (2018). The ecosystem as helix: an exploratory theory-building study of regional co-opetitive entrepreneurial ecosystems as Quadruple/Quintuple Helix Innovation Models. R\&D Management, 48(1), 148-162. https://doi.org/10.1111/radm.12300

Cardon, M. S., Gregoire, D. A., Stevens, C. E., \& Patel, P. C. (2013). Measuring entrepreneurial passion: Conceptual foundations and scale validation. Journal of Business Venturing, 28(3), 373-396. https://doi.org/10.1016/j.jbusvent.2012.03.003

Cardon, M. S., Wincent, J., Singh, J., \& Drnovsek, M. (2009a). The nature and experience of entrepreneurial passion. Academy of Management Review, 34(3), 511-532. https://doi.org/10.5465/amr.2009.40633190

Cardon, M. S., Wincent, J., Singh, J., \& Drnovsek, M. (2009b, July 1). The nature and experience of entrepreneurial passion. Academy of Management Review. Academy of Management. https://doi.org/10.5465/AMR.2009.40633190

CEPAL. (2018). Comisión Económica para América Latina y el Caribe. Progreso y evolución de la inserción de la mujer en actividades productivas y empresariales en América del Sur.

Chin, W. W. (1998). Issues and Opinion on Structural Equation Modeling. MIS Quarterly, 22(1), 1. https://doi.org/Editorial

Chin, W. W., \& Dibbern, J. (2010). Handbook of Partial Least Squares. Handbook of Partial Least Squares. https://doi.org/10.1007/978-3-540-32827-8

Costa, S. F., Santos, S. C., Wach, D., \& Caetano, A. (2018). Recognizing Opportunities across Campus: The Effects of Cognitive Training and Entrepreneurial Passion on the Business Opportunity Prototype. Journal of Small Business Management, 56(1), 51-75. https://doi.org/10.1111/jsbm.12348

De Carolis, D. M., \& Saparito, P. (2006). Social Capital, Cognition, and Entrepreneurial Opportunities: A Theoretical Framework. Entrepreneurship Theory and Practice, 30(1), 41-56. https://doi.org/10.1111/j.1540-6520.2006.00109.x

Deci, E. L., \& Ryan, R. M. (2016). Optimizing students' motivation in the era of testing and pressure: A self-determination theory perspective. In Building autonomous learners (pp. 9-29). Springer. https://doi.org/10.1007/978-981-287-630-0_2

Din, B. H., Anuar, A. R., \& Usman, M. (2016). The Effectiveness of the Entrepreneurship Education Program in Upgrading Entrepreneurial Skills among Public University Students. Procedia - Social and Behavioral Sciences, 224, 117-123. https://doi.org/10.1016/j.sbspro.2016.05.413

Drucker, P. (2012). Managing in the Next Society. Taylor \& Francis. https://doi.org/10.4324/9780080496283

Drucker, P. (2014). Innovation and entrepreneurship: practice and principles. https://doi.org/10.4324/9781315747453

Ernest, K., Matthew, S. K., \& Samuel, A. K. (2015). Towards Entrepreneurial Learning Competencies: The Perspective of Built Environment Students. Higher Education Studies, 5(1), 20-30. https://doi.org/10.5539/hes.v5n1p20

European Comission. (2018). COM(2018)24/F1 - ES. Retrieved from https://ec.europa.eu/epsc/file/strategic-note-13-future-work_en.

Fatoki, O., \& Patswawairi, T. (2012). The Motivations and Obstacles to Immigrant Entrepreneurship in South Africa. Journal of Social Sciences, 32(2), 133-142. https://doi.org/10.1080/09718923.2012.11893059

Forkmann, S., Henneberg, S. C., Naudé, P., \& Mitrega, M. (2016). Supplier relationship management capability: a qualification and extension. Industrial Marketing Management, 57, 185-200. https://doi.org/10.1016/j.indmarman.2016.02.003

GEM. (2017). GEM Global Entrepreneurship Monitor. Retrieved June 15, 2018, from https://www.gemconsortium.org/report 
GEM. (2018). Global Entrepreneurship Monitor. Global Report, Entreprenuer and Innovation 2017-2018. Retrieved from https://www.gemconsortium.org/report

Gibb, A. (2007). Enterprise in Education. Educating Tomorrow's Entrepreneurs. Pentti Mankinen, 1-17. https://doi.org/10.1145/237218.237249

Gomes da Costa Pedro Mares, T. (2016). Factors affecting students' entrepreneurial intentions of polytechnic institute of setubal: a cognitive approach fatores que afetam as intenções empreendedoras dos alunos do Instituto Politécnico de Setubal: uma abordagem cognitiva. Fundace.Org.Br, 7(1), 102-117. https://doi.org/10.13059/racef.v7i1.175

Hair, J. F., Hult, G. T. M., Ringle, C. M., Sarstedt, M., \& Thiele, K. O. (2017). Mirror, mirror on the wall: a comparative evaluation of composite-based structural equation modeling methods. Journal of the Academy of Marketing Science, 45(5), 616-632. https://doi.org/10.1007/s11747-017-0517-x

Henseler, J., Hubona, G., \& Ray, P. A. (2016). Using PLS path modeling in new technology research: updated guidelines. Industrial Management \& Data Systems, $116(1), \quad 2-20$. https://doi.org/10.1108/IMDS-09-2015-0382

Henseler, J., Ringle, C. M., \& Sarstedt, M. (2015). A new criterion for assessing discriminant validity in variance-based structural equation modeling. Journal of the Academy of Marketing Science, 43(1), 115-135. https://doi.org/10.1007/s11747-014-0403-8

Hornsby, J. S., Messersmith, J., Rutherford, M., \& Simmons, S. (2018). Entrepreneurship Everywhere: Across Campus, Across Communities, and Across Borders. Journal of Small Business Management, 56(1), 4-10. https://doi.org/10.1111/jsbm. 12386

Ip, C. Y., Liang, C., Wu, S. C., Law, K. M. Y., \& Liu, H. C. (2018). Enhancing Social Entrepreneurial Intentions through Entrepreneurial Creativity: A Comparative Study Between Taiwan and Hong Kong. Creativity Research Journal, 30(2), 132-142. https://doi.org/10.1080/10400419.2018.1446744

Jiménez, A., Palmero-Cámara, C., González-Santos, M. J., Gonzalez-Bernal, J., \& Jiménez-Eguizábal, J. A. (2015). The impact of educational levels on formal and informal entrepreneurship. BRQ Business Research Quarterly, 18(3), 204-212. https://doi.org/10.1016/j.brq.2015.02.002

Jiménez-jiménez, D., \& Sanz-valle, R. (2011). Innovation, organizational learning , and performance. Journal of Business Research, 64(4), 408-417. https://doi.org/10.1016/j.jbusres.2010.09.010

Joseph F. Hair, Jr., Marko Sarstedt, Christian M. Ringle, S. P. G. (2017). Advanced Issues in Partial Least Squares Structural Equation Modeling - Joseph F. Hair, Jr., Marko Sarstedt, Christian M. Ringle, Siegfried P. Gudergan - Google Libros (SAGE, Ed.). https://doi.org/10.1007/978-3-319-05542-8_15-1

Kalitanyi, V., \& Bbenkele, E. (2019). Measuring University Students' Perceptions About the Role of Self-efficacy on Entrepreneurial Intentions in Cape Town. Journal of Entrepreneurship and Innovation in Emerging Economies, 5(2), 214-232. https://doi.org/10.1177/2393957519863900

Kasemsap, K. (n.d.). The Importance of Entrepreneurship in Global Business (pp. 92-115). https://doi.org/10.4018/978-1-5225-1031-4.ch006

Kauanui, S. K., Thomas, K. D., Rubens, A., \& Sherman, C. L. (2010). Entrepreneurship and Spirituality: A Comparative Analysis of Entrepreneurs' Motivation. Journal of Small Business and Entrepreneurship, 23(4), 621-635. https://doi.org/10.1080/08276331.2010.10593505

Kautonen, T., van Gelderen, M., \& Fink, M. (2015). Robustness of the Theory of Planned Behavior in Predicting Entrepreneurial Intentions and Actions. Entrepreneurship Theory and Practice, 39(3), 655-674. https://doi.org/10.1111/etap.12056

Kautonen, T., van Gelderen, M., \& Tornikoski, E. T. (2013). Predicting entrepreneurial behaviour: a test of the theory of planned behaviour. Applied Economics, 45(6), 697-707. https://doi.org/10.1080/00036846.2011.610750

Kirby, D. A. (2004). Entrepreneurship Education: Can Business Schools Meet the Challenge? The role of universities in the innovation process in Egypt View project Entrepreneurship Education: Can Business Schools Meet the Challenge? Emerald.Com, 46, 510-519. https://doi.org/10.1108/00400910410569632

Littunen, H. (2000). Entrepreneurship and the characteristics of the entrepreneurial personality. International Journal of Entrepreneurial Behaviour \& Research, 6(6), 295-310. https://doi.org/10.1108/13552550010362741 
Liu, J., \& Gu, J. (2017). Journal of Education and Practice www.iiste.org ISSN (Vol. 8). Online. Retrieved from www.iiste.org

Mahendra, A. M., Djatmika, E. T., \& Hermawan, A. (2017). The Effect of Entrepreneurship Education on Entrepreneurial Intention Mediated by Motivation and Attitude among Management Students, State University of Malang, Indonesia. International Education Studies, 10(9), 61. https://doi.org/10.5539/ies.v10n9p61

McClelland, D. C. (1965). Achievement motivation can be developed. Houston, Tex.: American Institute of Motivation.

Miller, D., \& Le Breton-Miller, I. (2017). Underdog Entrepreneurs: A Model of Challenge-Based Entrepreneurship. Entrepreneurship: Theory and Practice, 41(1), 7-17. https://doi.org/10.1111/etap.12253

Mishra, C. S., \& Zachary, R. K. (2014). The theory of entrepreneurship : creating and sustaining entrepreneurial value. Springer International Publishing. https://doi.org/10.1057/9781137371461_10

Mitchell, R. K., Busenitz, L. W., Bird, B., Marie Gaglio, C., McMullen, J. S., Morse, E. A., \& Smith, J. B. (2007) The Central Question in Entrepreneurial Cognition Research 2007. Entrepreneurship Theory and Practice, 31(1), 1-27. https://doi.org/10.1111/j.1540-6520.2007.00161.x

Mueller, S. L., \& Thomas, A. S. (2001). Culture and entrepreneurial potential: A nine country study of locus of control and innovativeness. Journal of Business Venturing, 16(1), 51-75. https://doi.org/10.1016/S0883-9026(99)00039-7

Nawaser, K., Khaksar, S. M. S., \& Shakhsian, F. (2011). Motivational and Legal Barriers of Entrepreneurship Development. International Journal of Business and Management, 6(11), 112-118. https://doi.org/10.5539/ijbm.v6n11p112

Neneh, B. N. (2019). From entrepreneurial intentions to behavior: The role of anticipated regret and proactive personality. Journal of Vocational Behavior, 112, 311-324. https://doi.org/10.1016/j.jvb.2019.04.005

OECD. (2017). The Organization for Economic Cooperation and Development. Perspectivas económicas de América Latina 2017. https://doi.org/10.1787/leo-2017-es

OECD. (2019). The Organisation for Economic Cooperation and Development. Educación Superior en México RESULTADOS Y RELEVANCIA PARA EL MERCADO LABORAL Resumen / Evaluación y recomendaciones. https://doi.org/10.1787/9789264309432-en

Real, J. C., Roldán, J. L., \& Leal, A. (2014). From Entrepreneurial Orientation and Learning Orientation to Business Performance: Analysing the Mediating Role of Organizational Learning and the Moderating Effects of Organizational Size. British Journal of Management, 25(2), 186-208. https://doi.org/10.1111/j.1467-8551.2012.00848.x

Ringle, C., Wende, S., \& Becker, J. (2017). SmartPLS—Statistical Software For Structural Equation Modeling. Retrieved

from https://scholar.google.es/scholar?hl=es\&as_sdt=0\%2C5\&q=Ringle $\% 2 \mathrm{C}+$ Wende $\% 2 \mathrm{C}+\% 26+$ Becker $\% 2 \mathrm{C}+2$ 017+SMARTPLS\&btnG $=$

Robertson, M., Collins, A., Medeira, N., \& Slater, J. (2003). Barriers to start-up and their effect on aspirant entrepreneurs. Education + Training, 45(6), 308-316. https://doi.org/10.1108/00400910310495950

Rosique-Blasco, M., Madrid-Guijarro, A., \& García-Pérez-de-Lema, D. (2018). The effects of personal abilities and self-efficacy on entrepreneurial intentions. International Entrepreneurship and Management Journal, 14(4), 1025-1052. https://doi.org/10.1007/s11365-017-0469-0

Ryan, R. M., \& Deci, E. L. (2000). Self-determination theory and the facilitation of intrinsic motivation, social $\begin{array}{lllll}\text { development, and } \quad \text { well-being. } & \text { American }\end{array}$ https://doi.org/10.1037/0003-066X.55.1.68

Ryan, R. M., \& Deci, E. L. (2000). Self-determination theory and the facilitation of intrinsic motivation, social development, and well-being. American Psychologist, 55(1), 68. https://doi.org/10.1037/0003-066X.55.1.68

Ryan, R., \& Deci, E. (2017). Self-determination theory: Basic psychological needs in motivation, development, and wellness. Retrieved from https://books.google.es/books?hl=es\&lr=\&id=Bc_DDAAAQBAJ\&oi=fnd\& $\mathrm{pg}=\mathrm{PP} 1 \& \mathrm{dq}=$ self + determination + theory + motivation $+\&$ ots $=$ QHnck9iO5i\&sig=z7y2FXtBt4uofj_K6oct5Ex mHBI 
Schuberth, F., Henseler, J., \& Dijkstra, T. K. (2018). Partial least squares path modeling using ordinal categorical indicators. Quality \& Quantity, 52(1), 9-35. https://doi.org/10.1007/s11135-016-0401-7

Schumpeter, J. A. (2000). Entrepreneurship as Innovation.

Shepherd, D. A., Patzelt, H., Shepherd, D. A., \& Patzelt, H. (2018). Motivation and Entrepreneurial Cognition. In Entrepreneurial Cognition (pp. 51-103). Springer International Publishing. https://doi.org/10.1007/978-3-319-71782-1_3

Sirelkhatim, F., \& Gangi, Y. (2015). Entrepreneurship education: A systematic literature review of curricula contents and teaching methods. Cogent Business \& Management, 2(1). https://doi.org/10.1080/23311975.2015.1052034

Śledzik, K. (2013). Schumpeter's View on Innovation and Entrepreneurship. SSRN Electronic Journal. https://doi.org/10.2139/ssrn.2257783

Smith, K., \& Beasley, M. (2011). Graduate entrepreneurs: Intentions, barriers and solutions. Education and Training, 53(8), 722-740. https://doi.org/10.1108/00400911111185044

Smith, R. M., Sardeshmukh, S. R., \& Combs, G. M. (2016). Understanding gender, creativity, and entrepreneurial intentions. Education and Training, 58(3), 263-282. https://doi.org/10.1108/ET-06-2015-0044

Stewart, W. H., \& Roth, P. L. (2007). A Meta-Analysis of Achievement Motivation Differences between Entrepreneurs and Managers*. Journal of Small Business Management, 45(4), 401-421. https://doi.org/10.1111/j.1540-627X.2007.00220.x

Teece, D. J. (2010). Business models, business strategy and innovation. Long Range Planning, 43(2-3), 172-194. https://doi.org/10.1016/j.lrp.2009.07.003

Tipu, S. A. A. (2015). The Cognitive Side of Entrepreneurial Ethics: What Do We Still Need to Know? Journal of Enterprising Culture, 23(01), 117-137. https://doi.org/10.1142/S0218495815710016

UNESCO. (2018). United Nations Educational, Scientific and Cultural Organization. La Educación, una utopia necesaria. Digital Library. Retrieved from https://unesdoc.unesco.org/ark:/48223/pf0000261279_spa

Yar, D. H., Wennberg, W., \& Berglund, H. (2008). Creativity in entrepreneurship education. Journal of Small Business and Enterprise Development, 15(2), 304-320. https://doi.org/10.1108/14626000810871691

Zahra, A. S., Sapienza, J. H., \& Davidsson, P. (2006). Entrepreneurship and Dynamic Capabilities: A Review, Model and Research Agenda. Journal of Management Studies, 43(4), 917-955. https://doi.org/10.1111/j.1467-6486.2006.00616.x

Zahra, S. A. (2008). Being entrepreneurial and market driven: implications for company performance. Journal of Strategy and Management, 1(2), 125-142. https://doi.org/10.1108/17554250810926339

Zahra, S. A., \& Nambisan, S. (2012). Entrepreneurship and strategic thinking in business ecosystems. Business Horizons, 55(3), 219-229. https://doi.org/10.1016/j.bushor.2011.12.004

Zahra, S. A., \& Wright, M. (2011). Entrepreneurship's Next Act. Academy of Management Perspectives, 25(4), 67-83. https://doi.org/10.5465/amp.2010.0149

Zahra, S. A., \& Wright, M. (2016). Understanding the social role of entrepreneurship. Journal of Management Studies, 53(4), 610-629. Retrieved from https://onlinelibrary.wiley.com/doi/abs/10.1111/joms. 12149

Zahra, S. A., Newey, L. R., \& Shaver, J. M. (2011). Academic Advisory Boards' Contributions to Education and Learning: Lessons From Entrepreneurship Centers. Academy of Management Learning \& Education, 10(1), 113-129. https://doi.org/10.5465/amle.10.1.zqr113

Zampetakis, L. A., \& Moustakis, V. (2006). Linking creativity with entrepreneurial intentions: A structural approach. International Entrepreneurship and Management Journal, 2(3), 413-428. https://doi.org/10.1007/s11365-006-0006-z

Zellweger, T., Sieger, P., \& Halter, F. (2011). Should I stay or should I go? Career choice intentions of students with family business background. Journal of Business Venturing, 26(5), 521-536. https://doi.org/10.1016/j.jbusvent.2010.04.001 


\section{Appendix A}

Survey (Entrepreneurial Intention and Creativity)

\section{Block I}
A1. Age years old

A2. $\square$ Male $\square$ Female

A3 Name of the bachelor's degree

A4. Have you ever completed a course or program related to entrepreneurship? $\square$ Yes $\quad \square$ No

\section{Block II}

Please indicate to what extent you agree or disagree with the following statements:

\begin{tabular}{|c|c|c|c|c|c|c|c|}
\hline \multirow[b]{2}{*}{ Barriers to creativity } & \multicolumn{7}{|c|}{ Strongly disagree -Strongly agree } \\
\hline & 1 & 2 & 3 & 4 & 5 & 6 & 7 \\
\hline \multicolumn{8}{|l|}{ Intrinsic barriers to creativity } \\
\hline IBC1. Lack of skill or experience in creativity & $\square$ & $\square$ & $\square$ & $\square$ & $\square$ & $\square$ & $\square$ \\
\hline IBC2. Being unwilling to do different things & $\square$ & $\square$ & $\square$ & $\square$ & $\square$ & $\square$ & $\square$ \\
\hline IBC3. Lack of ability to evaluate new ideas & $\square$ & $\square$ & $\square$ & $\square$ & $\square$ & $\square$ & $\square$ \\
\hline IBC4. Insufficient time to think creatively & $\square$ & $\square$ & $\square$ & $\square$ & $\square$ & $\square$ & $\square$ \\
\hline \multicolumn{8}{|l|}{ Extrinsic barriers to creativity } \\
\hline EBC1. Follow cultural behavior patterns & $\square$ & $\square$ & $\square$ & $\square$ & $\square$ & $\square$ & $\square$ \\
\hline EBC2. Aversion to social changes & $\square$ & $\square$ & $\square$ & $\square$ & $\square$ & $\square$ & $\square$ \\
\hline EBC3. Lack of external motivation to develop creative activities & $\square$ & $\square$ & $\square$ & $\square$ & $\square$ & $\square$ & $\square$ \\
\hline Entrepreneurial Passion & 1 & 2 & 3 & 4 & 5 & 6 & 7 \\
\hline \multicolumn{8}{|l|}{ Passion to create } \\
\hline EPC1. Creating a new company excites me. & $\square$ & $\square$ & $\square$ & $\square$ & $\square$ & $\square$ & $\square$ \\
\hline EPC2. Owning my own company gives me energy & $\square$ & $\square$ & $\square$ & $\square$ & $\square$ & $\square$ & $\square$ \\
\hline $\begin{array}{l}\text { EPC3. Nurturing a new business through its emerging success is } \\
\text { pleasant. }\end{array}$ & $\square$ & $\square$ & $\square$ & $\square$ & $\square$ & $\square$ & $\square$ \\
\hline \multicolumn{8}{|l|}{ Passion to develop } \\
\hline EPI1. I really like to find the right people to market my product / service & $\square$ & $\square$ & $\square$ & $\square$ & $\square$ & $\square$ & $\square$ \\
\hline EPI2. It is exciting to gather the right people to work in my business. & $\square$ & $\square$ & $\square$ & $\square$ & $\square$ & $\square$ & $\square$ \\
\hline $\begin{array}{l}\text { EPI3. Pushing my colleagues and myself to make our project better } \\
\text { motivates me. }\end{array}$ & $\square$ & $\square$ & $\square$ & $\square$ & $\square$ & $\square$ & $\square$ \\
\hline EPI4. Growing and growing businesses is an important part of who I am & $\square$ & $\square$ & $\square$ & $\square$ & $\square$ & $\square$ & $\square$ \\
\hline \multicolumn{8}{|l|}{ Passion to invent } \\
\hline $\begin{array}{l}\text { EPD1. It is exciting to discover new ways to solve the unmet market } \\
\text { needs that can be marketed. }\end{array}$ & $\square$ & $\square$ & $\square$ & $\square$ & $\square$ & $\square$ & $\square$ \\
\hline EPD2. I find it nice to look for new ideas for products / services to offer. & $\square$ & $\square$ & $\square$ & $\square$ & $\square$ & $\square$ & $\square$ \\
\hline $\begin{array}{l}\text { EPD3. I am motivated to discover how to improve existing products / } \\
\text { services. }\end{array}$ & $\square$ & $\square$ & $\square$ & $\square$ & $\square$ & $\square$ & $\square$ \\
\hline $\begin{array}{l}\text { EPD4. Scanning the environment for new opportunities really excites } \\
\text { me. }\end{array}$ & $\square$ & $\square$ & $\square$ & $\square$ & $\square$ & $\square$ & $\square$ \\
\hline Entrepreneurial Intention (EI) & 1 & 2 & 3 & 4 & 5 & 6 & 7 \\
\hline
\end{tabular}




\begin{tabular}{|l|l|l|l|l|l|l|l|}
\hline IE1. I am prepared to do anything to be an entrepreneur & $\square$ & $\square$ & $\square$ & $\square$ & $\square$ & $\square$ & $\square$ \\
\hline IE2. My professional goal is to become an entrepreneur & $\square$ & $\square$ & $\square$ & $\square$ & $\square$ & $\square$ & $\square$ \\
\hline IE3. I am determined to create a company in the future & $\square$ & $\square$ & $\square$ & $\square$ & $\square$ & $\square$ & $\square$ \\
\hline IE4. I have thought seriously about the possibility of starting a business & $\square$ & $\square$ & $\square$ & $\square$ & $\square$ & $\square$ \\
\hline IE5. I intend to start a company someday & $\square$ & $\square$ & $\square$ & $\square$ & $\square$ & $\square$ & $\square$ \\
\hline
\end{tabular}

\section{Copyrights}

Copyright for this article is retained by the author(s), with first publication rights granted to the journal.

This is an open-access article distributed under the terms and conditions of the Creative Commons Attribution license (http://creativecommons.org/licenses/by/4.0/). 